\title{
PENGARUH KEADILAN KOMPENSASI DAN DUKUNGAN ORGANISASI TERHADAP KINERJA KARYAWAN DENGAN MOTIVASI INTRINSIK SEBAGAI VARIABEL MODERASI
}

\author{
Fikah Fairuzakiyah ${ }^{1}$, Ratno Purnomo', Ade Irma Anggraeni1 \\ 1Program Pascasarjana Magister Manajemen Universitas Jendral Soedirman Purwokerto \\ *Email corresponding author: Fairuzakiyah7@gmail.com
}

\begin{abstract}
Penelitian ini dilakukan dengan tujuan untuk menganalisis keadilan kompensasi dan dukungan organisasi terhadap kinerja karyawan dengan motivasi intrinsik sebagai variabel moderasi di PT. Bina Artha Ventura Cabang Tegal dan Brebes. Penelitian ini merupakan penelitian kuantitatif, menggunakan analisis regresi linier berganda dan Moderated Regression Analysis. Lokasi penelitian dilaksanakan di PT. Bina Artha Ventura Cabang Tegal dan Brebes. Populasi dalam penelitian ini semua karyawan PT. Bina Artha Ventura Cabang Tegal dan Brebes. Teknik pengambilan sampel menggunakan metode purposive sampling, Kriteria sampel dalam penelitian ini yakni karyawan posisi admin, relationship officer, dan sales officer. Jumlah sampel penelitian sebanyak 60 responden. Hasil penelitian ini adalah Keadilan kompensasi berpengaruh positif signifikan terhadap kinerja karyawan PT. Bina Artha Ventura. Dukungan organisasi berpengaruh positif signifikan terhadap kinerja karyawan PT. Bina Artha Ventura. Motivasi Intrinsik sebagai variabel pemoderasi memperkuat pengaruh keadilan kompensasi terhadap kinerja karyawan. Motivasi Intrinsik sebagai variabel pemoderasi memperkuat pengaruh dukungan organisasi terhadap kinerja karyawan tinggi.
\end{abstract}

Kata kunci: keadilan kompensasi, dukungan organisasi, motivasi intrinsik, kinerja karyawan

\begin{abstract}
This research was conducted with the aim to analyze the fairness of compensation and organizational support for employee performance with intrinsic motivation as a moderating variable at PT. Bina Artha Ventura Branch Tegal and Brebes. This research is a quantitative research, using multiple linear regression analysis and Moderated Regression Analysis. The location of the research was carried out at PT. Bina Artha Ventura Branch Tegal and Brebes. The population in this study were all employees of PT. Bina Artha Ventura Branch Tegal and Brebes. The sampling technique uses purposive sampling method, the sample criteria in this study are admin position employees, relationship officers, and sales officers. The number of research samples is 60 respondents. The results of this study are Justice compensation has a significant positive effect on the performance of employees of PT. Bina Artha Ventura. Organizational support has a significant positive effect on the performance of employees of PT. Bina Artha Ventura. Intrinsic motivation as a moderating variable strengthens the influence of justice compensation on employee performance. Intrinsic motivation as a moderating variable strengthens the influence of organizational support on high employee performance.
\end{abstract}

Keywords: fairness compensation, organizational support, intrinsic motivation, employee performance

\section{PENDAHULUAN}

Robbins (2006:4) mengemukakan bahwa organisasi adalah kesatuan (entity) sosial yang dikoordinasikan dengan batasan yang dapat diidentifikasi, yang bekerja secara terus menerus guna memenuhi tujuan organisasi. Organisasi harus memiliki tujuan yang jelas untuk mengarahkan sumber daya manusia yang terlibat didalamnya. Sebuah organisasi dalam menjalankan kegiatan untuk mencapai tujuannya memiliki faktor yang saling berpengaruh. Salah satu faktornya yaitu organisasi dituntut untuk mengelola dan mengoptimalkan sumber daya manusianya, terutama jika organisasi sedang menghadapi permasalahan kinerja karyawan. Semakin tinggi kemampuan karyawan, semakin tinggi pula kinerjanya. Dan sebaliknya, semakin rendah kemampuan karyawan, semakin rendah pula kinerjanya. Kinerja yakni hasil kerja yag dicapai karyawan dalam menjalankan tugas dan kewajiban pekerjaannya sesuai dengan 
tanggung jawab yang telah diberikan kepadanya. Rendahnya kinerja karyawan menjadi sebuah permasalahan dalam organisasi sehingga harus diidentifikasi penyebab dan cara menanganinya.

Karyawan adalah unsur penting dalam organisasi yang harus diperhatikan sehingga harapannya dapat memberikan kontribusi lebih optimal untuk kesuksesan organisasi. Aktivitas manajemen akan berjalan lancar apabila organisasi memiliki karyawan kompeten, berkontribusi secara optimal dalam mengelola organisasi dan mempunyai motivasi dari dalam dirinya. Pentingnya menjaga motivasi karyawan dalam meningkatkan kinerja karyawan karena motivasi intrinsik merupakan suatu dorongan yang ada dalam diri karyawan yang mendorong mereka untuk bekerja. Seseorang tentu tidak akan melakukan pekerjaan mereka jika tidak memiliki motivasi pada dirinya sendiri untuk melakukannya. Karyawan yang dalam bekerja tidak mempunyai motivasi, tidak merasa puas, tidak mendapat keadilan dalam pemberian kompensasi, tidak diperhatikan oleh organisasi akan cenderung tidak fokus dalam bekerja dan tidak dapat berkontribusi penuh terhadap pekerjaannya akibatnya menyebabkan kinerjanya menurun.

PT. Bina Artha Ventura merupakan lembaga keuangan yang berusia lebih dari lima tahun, telah memiliki divisi-divisi yang mendukung proses bisnis perusahaan dan memiliki banyak kantor cabang yang tersebar di seluruh wilayah Indonesia. Bina Artha Ventura adalah lembaga permodalan yang menawarkan jaminan bebas modal kerja untuk wanita dari rumah tangga miskin dan berpenghasilan rendah. Aktifitas para karyawan diharapkan ikut andil berperan dalam memajukan perekonomian Indonesia. Sehingga semestinya pada lembaga inilah para karyawan bekerja secara optimal demi kemajuan perekonomian khususnya di kabupaten Tegal dan Brebes.

Berdasarkan data informasi laporan portofolio harian ditemukan masalah terkait rendahnya kinerja karyawan PT. Bina Artha Ventura. Berikut adalah persentase pencapaian kinerja karyawan PT. Bina Artha Ventura tahun 2017.

Tabel 1 Pencapaian Kinerja Karyawan dan Klasifikasi Nilai Capaian Kinerja PT. Bina Artha Ventura tahun 2017.

\begin{tabular}{lc}
\hline \multicolumn{1}{c}{ Unsur-Unsur Penilaian Kinerja Karyawan } & Capaian Kerja \\
\hline Kejujuran & $70 \%$ \\
Kehadiran & $60 \%$ \\
Tanggung Jawab & $60 \%$ \\
Kerjasama & $70 \%$ \\
Prestasi Kerja & $50 \%$ \\
\hline Rata-rata Kinerja & $\mathbf{6 2 \%}$ \\
\hline Klasifikasi nilai capaian kinerja & Predikat \\
\hline Lebih dari 85\% & Sangat Baik \\
\hline $70-84 \%$ & Baik \\
\hline $69-50 \%$ & Kurang Baik \\
\hline Kurang dari 50\% & Buruk \\
\hline Sumber: data PT. Bina Artha Ventura
\end{tabular}

Sumber: data PT. Bina Artha Ventura

Tabel 1.1 menunjukkan hasil kinerja karyawan PT. Bina Artha Ventura yang kurang baik, terutama pada indikator prestasi kerja sehingga dapat diketahui adanya masalah kinerja karyawan. Buruknya pencapaian kinerja ini perlu segera dicarikan solusinya, karena dapat menghambat pencapaian tujuan organisasi nantinya.

Kinerja karyawan ditentukan oleh banyak faktor, berdasarkan literatur dan penelitian sebelumnya yaitu penelitian Ghosh et al. (2017), Hidayat et al. (2017), Afzali et al. (2014) Ni Made S (2016) menyatakan bahwa beberapa faktor yang mempunyai pengaruh terhadap kinerja 
karyawan diantaranya keadilan kompensasi, dukungan organisasi dan faktor moderasi motivasi kerja intrinsik.

Faktor yang mempengaruhi kinerja karyawan menurut penelitian Ghosh et al. (2017) yaitu keadilan kompensasi yang hasilnya menyatakan keadilan kompensasi mempunyai pengaruh terhadap kinerja karyawan dan keadilan prosedural lebih kuat pengaruhnya terhadap kinerja daripada keadilan distributif. Kompensasi itu penting bagi organisasi sebab kompensasi mencerminkan upaya organisasi dalam mempertahankan dan meningkatkan kesejahteraan karyawannya. Pemberian kompensasi juga sebagai bentuk usaha mencapai kesuksesan organisasi. Penelitian Hidayat et al. (2017) mengemukakan keadilan distributif kompensasi dan keadilan prosedural kompensasi berpengaruh positif terhadap kinerja. Salah satu cara agar tujuan organisasi tercapai dengan memperlakukan sumber daya manusia secara adil, pemberian kompensasi karyawan sesuai beban pekerjaan dan juga hasil kerjanya. Imbalan juga diharapkan setara dengan karyawan lain yang berada dalam lini pekerjaan yang sama. Jika karyawan sudah merasakan adanya keadilan kompensasi yang diberikan kepadanya maka ia akan tetap semangat bekerja sehingga timbul produktivitas kerja yang tinggi dalam organisasi.

Selanjutnya faktor yang mempengaruhi kinerja karyawan yaitu faktor dukungan organisasi, menurut penelitian Afzali et al. (2014) mengemukakan bahwa dukungan organisasi mempunyai peran penting dan secara signifikan mempengaruhi kinerja. Organisasi harus memperhatikan faktor dukungan organisasi yang mempengaruhi kinerja karyawan yaitu mengenai bagaimana dukungan organisasi mengakui kontribusi dan kesejahteraan karyawannya. Hasil penelitian Ni Made S (2016) mengemukakan bahwa dukungan organisasi berpengaruh terhadap kinerja karyawan. Jika karyawan menganggap dukungan organisasi yang diterimanya tinggi, maka karyawan tersebut akan menyatukan keanggotaan sebagai anggota organisasi ke dalam identitas diri mereka dan kemudian mengembangkan hubungan dan persepsi yang lebih positif terhadap organisasi tersebut. Karyawan yang telah menyatukan keanggotaan dalam organisasi dengan identitasnya, maka karyawan tersebut akan lebih bertanggung jawab untuk berkontribusi dan memberikan kinerja terbaik demi kemajuan organisasinya.

Salah satu variabel yang ditemukan mempengaruhi hubungan kepuasan kerja dan kompensasi dengan kinerja yaitu motivasi kerja (Muryanto, 2011). Penelitian Rianto (2017) dan Firmandari (2014) mengemukakan motivasi kerja sebagai variabel moderasi yang memperkuat pengaruh kepuasan kerja dan kompensasi terhadap kinerja karyawan. Organisasi perlu memperhatikan faktor motivasi intrinsik yang ada pada diri karyawan untuk bekerja agar tetap ada dan tetap fokus dalam mencapai tujuan organisasi. Motivasi intrinsik karyawan sangat penting karena motivasi adalah motor penggerak bagi setiap individu yang mendasari mereka untuk bertindak dan melakukan sesuatu. Seorang karyawan tidak akan melakukan sesuatu hal secara optimal apabila tidak mempunyai motivasi dari dalam dirinya sendiri untuk melalukan hal tersebut. Berbeda dengan hasil penelitian ini, penelitian Eko Muryanto (2011) mengemukakan bahwa motivasi bukan merupakan variabel moderasi, dengan kata lain motivasi memperlemah hubungan antara kompensasi terhadap kinerja pegawai. Hasil penelitian Hartiwi Prabowo (2012) mengemukakan bahwa kepuasan kerja yang dimoderasi variabel motivasi kerja berpengaruh signifikan terhadap kinerja karyawan, dimana jika seorang karyawan termotivasi untuk melakukan pekerjaannya dengan baik dan merasa puas atas pekerjaannya, maka karyawan tersebut akan bekerja maksimal untuk organisasi. Sedangkan hasil penelitian Eko Wijayanto (2013) yaitu tidak terbukti adanya pengaruh yang signifikan dari kepuasan kerja terhadap kinerja karyawan dengan dimoderasi motivasi kerja. 
Berdasarkan uraian diatas ditemukan perbedaan dari beberapa hasil penelitian, sehingga diketahui adanya suatu research gap yaitu pengaruh kompensasi terhadap kinerja karyawan yang dimoderasi variabel motivasi kerja, sehingga penelitian ini dilaksanakan untuk menguji ulang dan membuktikan secara empiris "pengaruh dan keadilan kompensasi, dukungan organisasi terhadap kinerja karyawan PT. Bina Artha Ventura dengan motivasi intrinsik sebagai variabel moderasi". Tujuan dari penelitian ini adalah untuk menganalisis dan mengetahui ada tidaknya pengaruh antara keadilan kompensasi dan dukungan organisasi terhadap kinerja karyawan dengan motivasi sebagai variabel moderasi di PT. Bina Artha ventura. Dengan mengetahui besarnya pengaruh tersebut, maka perusahaan akan lebih mudah dalam menentukan strategi yang tepat dan sesuai dengan kondisi serta permasalahan kinerja yang sedang dihadapi karyawan di PT. Bina Artha Ventura.

\section{TINJAUAN PUSTAKA}

\section{Kinerja Karyawan}

Mangkuprawira dan Hubeis (2007:153) mengemukakan kinerja adalah hasil dari proses pekerjaan tertentu secara terencana pada waktu dan tempat dari karyawan serta organisasi bersangkutan. Kinerja karyawan secara umum di pengaruhi oleh faktor-faktor yang berasal dari eksternal individu seperti lingkungan kerja, rekan kerja, dukungan atasan dan internal individu seperti motivasi dan kepribadian (Abdurrahman, 2019). Kinerja adalah hasil kerja yang dicapai seseorang dalam melaksanakan tugas-tugasnya atas kecakapan, usaha dan kesempatan (Hasibuan, 2002:160). Kinerja adalah hasil kerja secara kualitas dan kuantitas yang dicapai oleh seorang pegawai dalam melaksanakan tugasnya sesuai dengan tanggung jawab yang diberikan kepadanya (Mangkunegara, 2009:67). Simanjuntak (2005:1) mengemukakan kinerja adalah tingkat pencapaian hasil atas pelaksanakaan tugas tertentu. Informasi tentang kinerja karyawan merupakan suatu hal yang sangat penting digunakan untuk mengevaluasi apakah proses kinerja yang dilakukan organisasi selama ini sudah sejalan dengan tujuan yang diharapkan atau belum. Pada dasarnya kinerja seorang karyawan merupakan hal yang bersifat individual karena setiap karyawan mempunyai tingkat kemampuan yang berbeda-beda dalam mengerjakan tugas pekerjaannya. Handoko (2000:50) mengatakan bahwa kinerja yakni proses organisasi mengevaluasi prestasi kerja karyawan.

\section{Keadilan Kompensasi}

Kompensasi yaitu sesuatu yang dipertimbangkan sebagai suatu yang sebanding (Mangkunegara, 2009:83). Handoko (2001:155) menyatakan kompensasi yaitu semua yang diterima karyawan dengan tujuan sebagai balas jasa atas pekerjaannya. Cara perusahaan untuk meningkatkan kualitas karyawannya juga untuk pertumbuhan perusahaan dengan memberikan kompensasi yang adil. Organisasi satu dengan yang lain mempunyai sistem kompensasi yang berbeda sesuai dengan visi, misi, dan tujuan dari perusahaan tersebut. Setiap orang menginginkan perlakuan yang adil baik dari sisi distribusi dan prosedur atau disebut juga sebagai keadilan distributif dan keadilan prosedural (Tjahjono, 2007). Persepsi keadilan distributif menunjuk pada penilaian tentang keadilan hasil yang diterima sama jika dibandingkan dengan hasil yang diterima orang lain. Keadilan prosedural adalah persepsi keadilan prosedur yang digunakan untuk membuat keputusan sehingga setiap anggota organisasi dapat terlibat didalamnya.

\section{Dukungan Organisasi}

Rivai (2005:359) mengemukakan persepsi yakni proses kognitif seseorang dalam memahami sesuatu baik melalui penglihatan, pendengaran, maupun perasaan. Persepsi akan mempengaruhi penilaian seseorang terhadap organisasinya. Eisenberger dan Rhoades 
(2002:701) mengungkapkan persepsi terhadap dukungan organisasi yakni sejauh mana organisasi menilai kontribusi karyawan dan peduli pada kesejahteraan mereka. Persepsi terhadap organisasi dianggap sebagai sebuah keyakinan global yang dibentuk oleh setiap karyawan mengenai penilaian mereka terhadap kebijakan dan prosedur organisasi yang dibentuk berdasarkan pengalaman mereka, penerimaan sumber daya, interaksi dengan rekan organisasinya (supervisor) dan persepsi mereka mengenai kepedulian organisasi terhadap kesejahteraan mereka (Eisenberger dan Rhoades, 2002:698). Robbins (2008:103) mengemukakan dukungan organisasi yakni tingkat sampai dimana karyawan yakin organisasi menghargai kontribusi mereka dan peduli dengan kesejahteraan mereka.

\section{Motivasi Intrinsik}

Mathis dan Jackson (2000:89) motivasi yakni hasrat dalam diri seseorang yang menyebabkan orang tersebut melakukan tindakan. Hasibuan (2002:165) mendefinisikan motivasi yakni pemberian daya penggerak yang menciptakan kegairahan kerja seseorang, agar mereka mau bekerja untuk mencapai kepuasan. Handoko (2001:9) motivasi yakni faktor yang terdapat dalam diri manusia yang menimbulkan, menggerakkan dan mengorganisasikan tingkah lakunya.

Adapun model penelitian berdasarkan kajian teori yang telah di uraikan diatas, maka model teoritas yang diajukan adalah sebagai berikut:

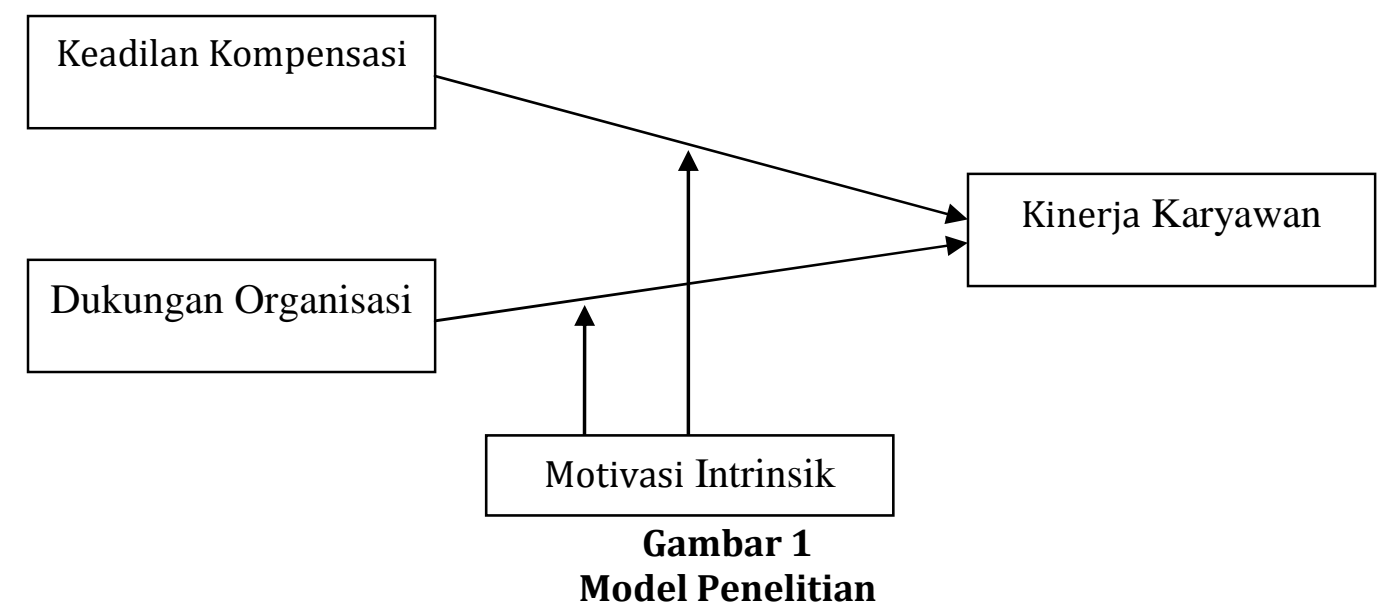

\section{PERUMUSAN HIPOTESIS}

Hipotesis dalam penelitian ini berdasarkan rumusan masalah, tinjauan pustaka dan penelitian terdahulu adalah :

$\mathrm{H}_{1}$ : Keadilan Kompensasi berpengaruh positif dan signifikan terhadap Kinerja Karyawan.

$\mathrm{H}_{2}$ : Dukungan Organisasi berpengaruh positif dan signifikan terhadap kinerja karyawan.

$\mathrm{H}_{3}$ : Motivasi Intrinsik sebagai variabel pemoderasi memperkuat pengaruh hubungan antara keadilan kompensasi terhadap kinerja karyawan.

$\mathrm{H}_{4}$ : Motivasi Intrinsik sebagai variabel pemoderasi memperkuat pengaruh hubungan antara dukungan organisasi terhadap kinerja karyawan.

\section{METODE PENELITIAN}

Metode analisis data yang digunakan dalam penelitian ini adalah metode deskriptif kuantitatif yaitu mencari dan mengumpulkan data yang diperlukan yang bersumber dari perusahaan yang akan diteliti. Data yang telah diperoleh diuraikan sehingga memberikan suatu gambaran bagi suatu peneliti. Data yang digunakan sebagai data kuantitatif dalam penelitian ini adalah data 
pencapaian kinerja karyawan tahun 2017. Metode pengumpulan data yang digunakan dalam penelitian ini dengan menggunakan data primer dan data sekunder. Data primer yang dilakukan dengan mengunakan kuesioner atau angket yang mendukung dan disesuaikan dengan tema penelitian. Sedangkan data sekunder berupa dokumen-dokumen data yang diperoleh untuk melengkapi penelitian. Populasinya yakni semua karyawan PT. Bina Artha Ventura Cabang Tegal dan Brebes. Teknik pengambilan sampel di dalam penelitian ini dengan menggunakan teknik purposive sampling. Kriteria sampel dalam penelitian ini yakni karyawan posisi admin, relationship officer, dan sales officer. Jadi jumlah sampel dalam penelitian ini berjumlah 60 orang. Metode analisis data yang digunakan dalam penelitian ini adalah analisis regresi linier berganda dan menggunakan analisis Moderated Regression Analysis atau MRA dengan menggunakan Software SPSS Versi 17. Penelitian ini menggunakan metode pengumpulan data yaitu kuisioner. Metode ini dilakukan dengan cara memberikan kuisioner kepada seluruh karyawan PT. bina Artha ventura dimana hasil kuesioner tersebut digunakan peneliti untuk melakukan penelitian.

\section{HASIL DAN PEMBAHASAN}

\section{Gambaran Umum Responden}

Responden penelitian ini adalah karyawan PT. Bina Artha ventura Tegal dan Brebes. Tingkat pengembalian kuesioner mencapai $100 \%$ yang kembali dan layak, hal ini disebabkan pada proses pengisian kuesioner peneliti mengarahkan dan menunggu saat itu juga sampai kuesioner selesai diisi sehingga memudahkan pengembalian kuesioner. Jumlah responden yang berjenis kelamin pria sebanyak 36 orang (60\%), jumlah ini lebih besar daripada yang berjenis kelamin wanita sebanyak 24 orang (40\%). Hal ini menunjukkan bahwa pada kantor Bina Artha Ventura pria lebih mendominasi dari pada wanita. Sebagian besar responden berusia $<30$ tahun sebanyak 56 orang $(93,33 \%)$. Dan responden yang berusia 31 sampai 40 tahun sebanyak 4orang $(6,67 \%)$. Banyaknya responden dengan pendidikan terakhir SMA/SMK sebesar 49 atau sekitar 81,67\% dari keseluruhan responden. Tingkat pendidikan terakhir D3/S1 dengan jumlah 11 orang atau sekitar $18,33 \%$ dari keseluruhan responden. Hasil deskriptif pendidikan terakhir dari responden menunjukkan bahwa mayoritas responden pada PT. Bina Artha Ventura cabang Tegal dan Brebes adalah orang yang memiliki pendidikan cukup rendah.

\section{Uji Validitas dan Reliabilitas Kuesioner}

Uji analisis validitas dan reliabilitas kuesioner penelitian ini meliputi variablel keadilan distributif kompensasi (X1), keadilan prosedural kompensasi (X2), dukungan organisasi (X3) Kinerja Karyawan (Y), dan motivasi intrinsik (Z). Dari hasil perhitungan menunjukkan bahwa item pertanyaan dan nilai koefisien reliabitas dari variabel keadilan distributif kompensasi (X1), keadilan prosedural kompensasi (X2), dukungan organisasi (X3), Kinerja Karyawan (Y), dan motivasi intrinsik $(\mathrm{Z})$ dalam kuesioner memiliki koefisien korelasi masing-masing lebih besar dari $r_{\text {tabel }}$ 0,2542 artinya semua pertanyaan dalam kuesioner dinyatakan valid dan reliabel, sehingga koesioner digunakan sebagai alat ukur penelitian ini.

\section{Uji Asumsi Klasik}

Berdasarkan perhitungan uji normalitas semua variabel berdistribusi normal yaitu nilai signifikansi dari uji Kolmogrof-Smirnov terhadap nilai standar residual hasil persamaan regresi 0,218 lebih besar dari $\alpha$ sebesar 0,05. Disimpulkan nilai residual terstandarisasi dinyatakan menyebar secara normal atau semua variabel berdistribusi normal. Untuk uji multikolinearitas diketahui bahwa nilai tolerance memiliki nilai lebih besar dari 0,10 dan nilai VIF lebih kecil dari 10,00 artinya dalam penelitian ini tidak terjadi multikolinieritas. Untuk uji Heteroskedastisitas, berdasarkan penelitian menunjukkan nilai rank spearman lebih besar dari nilai signifikansi $\alpha$ 0,05 (5\%) sehingga dapat disimpulkan tidak terjadi heteroskedastisitas pada model regresi. Sehingga dapat disimpulkan bahwa tidak ada hubungan antara variabel bebas dengan residual absolutnya dan model regresi layak dipake dan digunakan untuk memprediksi kinerja karyawan. 


\section{Pengujian Secara Statistik}

Tabel 2 Analisis Regresi Linear

\begin{tabular}{l|lll}
\hline Variabel & Koefisien regresi & thitung & P value (sig) \\
\hline (Constant) & 2,981 & 1,497 & 0,014 \\
Keadilan distributif kompensasi & 0,837 & 2,821 & 0,007 \\
Keadilan prosedural kompensasi & 0,381 & 2,008 & 0,050 \\
Dukungan organisasi & 0,384 & 2,809 & 0,009 \\
Fhitung: 13.843 & & & 0,000 \\
adjusted $\mathrm{R}^{2}: 0,465$ & & & \\
\hline
\end{tabular}

Sumber: Olah Data SPSS (2018)

a. Persamaan hasil analisis regresi linear sebagai berikut:

$\mathrm{Y}=2,981+0,873 \mathrm{X}_{1}+0,381 \mathrm{X}_{2}+0,384 \mathrm{X}_{3}$

a) Konstanta (a) $=2,981$ bertanda positif, artinya apabila variabel kepuasan kerja, keadilan distributif kompensasi, keadilan prosedural kompensasi dan dukungan organisasi sama dengan nol (0) maka kinerja adalah positif.

b) $b_{1}=0,074$ bertanda positif, artinya apabila variabel kepuasan kerja ditingkatkan, kinerja karyawan juga mengalami peningkatan dengan asumsi variabel keadilan distributif kompensasi, keadilan prosedural kompensasi dan dukungan organisasi dianggap tetap.

c) $\mathrm{b}_{2}=0,873$ bertanda positif, artinya apabila variabel keadilan distributif kompensasi ditingkatkan, kinerja karyawan juga mengalami peningkatan dengan asumsi variabel kepuasan kerja, keadilan prosedural kompensasi dan dukungan organisasi dianggap tetap. Nilai $b_{3}=0,381$ bertanda positif, artinya apabila variabel keadilan prosedural kompensasi ditingkatkan, kinerja karyawan juga mengalami peningkatan dengan asumsi variabel kepuasan kerja, keadilan distributif kompensasi dan dukungan organisasi dianggap tetap.

d) $\mathrm{b}_{4}=0,384$ bertanda positif, artinya apabila variabel dukungan organisasi ditingkatkan, kinerja karyawan juga mengalami peningkatan dengan asumsi variabel kepuasan kerja, keadilan distributif kompensasi dan keadilan prosedural kompensasi dianggap tetap.

b. Uji Signifikansi nilai t (Uji t)

a) Nilai t hitung 2,281 dan signifikansi 0,007 $<0,05$ sehingga keadilan distributif kompensasi berpengaruh signifikan terhadap kinerja karyawan. Hasil nilai t hitung 2,008 dan $p$ value $0,050<0,05$ sehingga keadilan prosedural kompensasi berpengaruh signifikan terhadap kinerja karyawan. Hasil uji statistik menunjukkan faktor keadilan distributif kompensasi dan keadilan prosedural kompensasi mempunyai pengaruh yang positif signifikan terhadap kinerja karyawan. Hipotesis kpertama $\left(\mathrm{H}_{1}\right)$ yang menyatakan bahwa keadilan kompensasi berpengaruh positif dan signifikan terhadap kinerja karyawan, diterima.

b) Nilai t hitung 2,809 dan signifikansi 0,009 $<0,05$ sehingga dukungan organisasi berpengaruh signifikan terhadap kinerja karyawan. Hasil uji statistik menunjukkan faktor dukungan organisasi mempunyai pengaruh terhadap kinerja karyawan. Hipotesis kedua $\left(\mathrm{H}_{2}\right)$ yang menyatakan bahwa dukungan organisasi berpengaruh positif dan signifikan terhadap kinerja karyawan, diterima.

c. Uji Signifikansi nilai F (uji F)

Nilai $\mathrm{F}$ hitung sebesar 13,843 dan $p$ value $0,000<0,05$ yang berarti secara simultan variabel kepuasan kerja, keadilan distirbutif kompensasi, keadilan prosedural kompensasi, dan dukungan organisasi berpengaruh terhadap kinerja karyawan.

d. Koefisien determinasi

Nilai adjusted $\mathrm{R}^{2}$ sebesar 0,465 artinya pengaruh variabel kepuasan kerja, keadilan distirbutif kompensasi, keadilan prosedural kompensasi, dan dukungan organisasi terhadap kinerja karyawan sebesar $46,5 \%$ dan sisanya sebesar 53,5\% dipengaruhi oleh variabel lain di luar model penelitian. 
Tabel 3 Uji Moderasi

\begin{tabular}{l|ccc}
\hline \multicolumn{1}{c|}{ Variabel } & Koefisien regresi & t hitung & P value (sig) \\
\hline (Constant) & 51,893 & 2,083 & 0,042 \\
Keadilan distributif & 4,090 & 2,879 & 0,006 \\
kompensasi & & & \\
Motivasi Intrinsik & 2,503 & 2,299 & 0,025 \\
Keadilan dis*Motivasi & 0,131 & 2,139 & 0,037 \\
& & & \\
Fhitung : 16,098 & & & 0,000 \\
adjusted $\mathrm{R}^{2}: 0,434$ & & \\
\hline
\end{tabular}

Sumber: Hasil Olah Data SPSS (2018)

Berdasarkan tabel, angka adjusted $\mathrm{R}^{2}$ sebesar 0,434 menunjukkan bahwa 43,4\% variabel kinerja dipengaruhi variabel keadilan distributif kompensasi. Nilai F hitung 16,098 signifikansi sebesar $0,000<0,05$. Artinya, keadilan distributif kompensasi, motivasi intrinsik serta interaksi antara keadilan distributif kompensasi dan motivasi intrinsik berpengaruh secara bersama-sama terhadap kinerja karyawan. Nilai $t$ hitung keadilan distributif kompensasi 2,879 signifikansi 0,006 $<0,05$ (signifikan). Variabel motivasi intrinsik mempunyai t hitung 2,299 signifikansi 0,025 $<0,05$ (signifikan). Interaksi variabel keadilan distributif dengan motivasi intrinsik mempunyai t hitung 2,139 signifikansi $0,037<0,05$ (signifikan). Artinya, motivasi intrinsik merupakan pemoderasi pengaruh keadilan distributif kompensasi terhadap kinerja karyawan.

Hasil Pengujian motivasi intrinsik dalam memoderasi pengaruh keadilan prosedural kompensasi terhadap kinerja karyawan

Tabel 4 Uji Moderasi

\begin{tabular}{l|ccc}
\hline \multicolumn{1}{c|}{ Variabel } & Koefisien regresi & thitung & P value (sig) \\
\hline (Constant) & 21,813 & 1,255 & 0,215 \\
Keadilan prosedural & 1,867 & 2,222 & 0,030 \\
kompensasi & 1,942 & 2,453 & 0,017 \\
Motivasi Intrinsik & 0,077 & 2,025 & 0,048 \\
Keadilan pro*Motivasi & & & 0,001 \\
Fhitung : 6,573 & & & \\
adjusted $\mathrm{R}^{2}: 0,221$ & & & \\
\hline
\end{tabular}

Sumber: Olah Data SPSS (2018)

Berdasarkan tabel, angka adjusted $\mathrm{R}^{2}$ sebesar 0,221 menunjukkan bahwa 22,1\% variabel kinerja dipengaruhi variabel keadilan prosedural kompensasi. Nilai $F$ hitung 6,573 signifikansi sebesar 0,000 $<0,05$. Artinya, keadilan prosedural kompensasi, motivasi intrinsik dan interaksi keadilan prosedural kompensasi dan motivasi intrinsik berpengaruh secara bersama-sama terhadap kinerja karyawan. Nilai t hitung keadilan prosedural kompensasi 2,222 signifikansi 0,030 $<0,05$ (signifikan). Variabel motivasi intrinsik mempunyai t hitung 2,453 signifikansi 0,017 <0,05 (signifikan). Interaksi variabel keadilan prosedural kompensasi dan motivasi intrinsik mempunyai t hitung 2,025 signifikansi 0,048 $<0,05$ (signifikan). Variabel motivasi intrinsik merupakan pemoderasi pengaruh keadilan prosedural kompensasi terhadap kinerja karyawan. Hipotesis ketiga $\left(\mathrm{H}_{3}\right)$ yang menyatakan motivasi intrinsik sebagai variabel pemoderasi memperkuat pengaruh keadilan kompensasi terhadap kinerja karyawan, diterima.

Hasil Pengujian motivasi intrinsik dalam memoderasi pengaruh dukungan organisasi terhadap kinerja karyawan

Tabel 5 Uji Moderasi

\begin{tabular}{l|lll}
\hline Variabel & Koefisien regresi & thitung & P value (sig) \\
\hline (Constant) & 9,907 & 6,554 & 0,041 \\
\hline
\end{tabular}




\begin{tabular}{l|lll}
\hline Dukungan organisasi & 2,396 & 2,065 & 0,042 \\
Motivasi Intrinsik & 2,218 & 2,337 & 0,022 \\
Duk. Orgnssi*Motivasi & 1,542 & 2,117 & 0,038 \\
& & & \\
Fhitung : 5.620 & & & 0,002 \\
adjusted $\mathrm{R}^{2}: 0,190$ & & \\
\hline
\end{tabular}

Sumber: Hasil Olah Data SPSS (2018)

Berdasarkan pada tabel, angka adjusted $\mathrm{R}^{2}$ 0,190 menunjukkan bahwa $19 \%$ variabel kinerja dipengaruhi variabel dukungan organisasi. Nilai F hitung 5,620 signifikansi 0,002< 0,05 . Artinya, dukungan organisasi, motivasi intrinsik serta interaksi antara dukungan organisasi dan motivasi intrinsik berpengaruh secara bersama-sama terhadap kinerja karyawan. Nilai t hitung dukungan organisasi 2,065 signifikansi 0,042 < 0,05 (signifikan). Nilai t hitung motivasi intrinsik 2,337 signifikansi 0,022 <0,05 (signifikan). Nilai t hitung interaksi variabel dukungan organisasi dan motivasi intrinsik 2,117 dengan signifikansi $0,038<0,05$ (signifikan). Variabel motivasi intrinsik merupakan pemoderasi pengaruh dukungan organisasi terhadap kinerja karyawan. Hipotesis keempat $\left(\mathrm{H}_{4}\right)$ yang menyatakan motivasi intrinsik sebagai variabel pemoderasi memperkuat pengaruh hubungan antara dukungan organisasi terhadap kinerja karyawan, diterima.

\section{Pembahasan}

Hipotesis pertama $\left(\mathrm{H}_{1}\right)$ yang menyatakan bahwa keadilan kompensasi berpengaruh positif dan signifikan terhadap kinerja karyawan, diterima. Hasil penelitian yaitu keadilan kompensasi baik keadilan distributif kompensasi maupun keadilan prosedural kompensasi mempunyai pengaruh positif dan signifikan terhadap kinerja karyawan PT. Bina Artha Ventura Cabang Tegal dan Brebes. Hal tersebut berarti bahwa semakin tinggi keadilan kompensasi karyawan PT. Bina Artha Ventura maka semakin tinggi tingkat kinerja karyawan. Temuan penelitian ini sejalan dengan penelitian Hidayat et al. (2017) yang menjelaskan adanya pengaruh positif signifikan antara keadilan kompensasi terhadap kinerja karyawan. Selanjutnya, penelitian ini juga konsisten dengan penelitian Suhartini (2005) bahwa keadilan merupakan jantunganya kompensasi. Pembagian kompensasi yang adil, karyawan akan termotivasi untuk meningkatkan kinerjanya. Kompensasi yang adil akan mempertahankan karyawan yang ada, adanya kompensasi yang sebanding dengan beban pekerjaannya maka ia akan tetap bekerja di organisasi karena semua kebutuhannya terpenuhi tetapi sebaliknya jika tidak adanya keadilan dalam pemberian kompensasi pada organisasi, karyawan tidak semangat bekerja karena kebutuhan yang tidak terpenuhi sehingga produktivitasnya juga rendah. Setiap orang menginginkan perlakuan yang adil baik dari sisi distribusi dan prosedur atau disebut juga sebagai keadilan distributif dan keadilan prosedural (Tjahjono, 2007)

Hipotesis kedua $\left(\mathrm{H}_{2}\right)$ yang menyatakan bahwa dukungan organisasi berpengaruh positif dan signifikan terhadap kinerja karyawan, diterima. Dukungan organisasi berpengaruh terhadap kinerja karyawan PT. Bina Artha Ventura Cabang Tegal dan Brebes. Persepsi karyawan terhadap dukungan organisasi mengenai penilaian mereka terhadap kebijakan dan prosedur organisasi, penerimaan sumber daya, interaksi dengan rekan organisasinya (supervisor) dan persepsi mereka mengenai kepedulian organisasi terhadap kesejahteraan mereka (Eisenberger dan Rhoades, 2002:698). Penelitian ini mendukung penelitian Afzali et al.(2014) yaitu adanya pengaruh positif signifikan dukungan organisasi terhadap kinerja karyawan. Karyawan akan melihat dan menilai dukungan yang diterimanya dari organisasi. Ketika karyawan menganggap dukungan organisasi yang diterimanya tinggi, menganggap dirinya sebagai bagian dari organisasi dan ikut bertanggung jawab dalam berkontribusi untuk organisasi maka dengan ini kinerja karyawan tersebut akan meningkat dan tujuan organisasi akan tercapai. Dukungan organisasi dalam hal ini yaitu kesejahteraan, tugas, respon pemimpin, kedekatan dan kerja sama.

Hipotesis ketiga $\left(\mathrm{H}_{3}\right)$ yang menyatakan motivasi intrinsik sebagai variabel pemoderasi memperkuat pengaruh keadilan kompensasi terhadap kinerja karyawan, diterima. Motivasi intrinsik memoderasi pengaruh keadilan kompensasi terhadap kinerja karyawan PT. Bina Artha Ventura Cabang Tegal dan Brebes. Sistem kompensasi yang adil merupakan hal penting dari manajemen sumber daya manusia karena dapat membantu, menarik dan mempertahankan 
karyawan yang berprestasi. Adanya pemberian dorongan motivasi pada karyawan, kompensasi yang adil, sehingga kinerja karyawan akan semakin meningkat. Setiap karyawan menginginkan perlakuan yang adil baik dari sisi keadilan distributif maupun prosedural. Kinerja karyawan akan lebih meningkat jika kompensasi dan motivasi kerjanya terpenuhi, sehingga tujuan organisasi maupun kebutuhan karyawan akan terpenuhi dan tercapai. Penelitian ini mendukung penelitian Firmandari (2014) yaitu motivasi memperkuat pengaruh kompensasi terhadap kinerja karyawan. Pengaruh keadilan kompensasi terhadap kinerja karyawan akan semakin kuat jika adanya motivasi dari dalam diri karyawan. Dengan adanya motivasi intrinsik terhadap karyawan, maka akan lebih meningkatkan hasil kinerja karyawan PT. Bina Artha Ventura.

Hipotesis keempat $\left(\mathrm{H}_{4}\right)$ yang menyatakan motivasi intrinsik sebagai variabel pemoderasi memperkuat pengaruh hubungan antara dukungan organisasi terhadap kinerja karyawan, diterima. Motivasi intrinsik memoderasi pengaruh dukungan organisasi terhadap kinerja karyawan. Penelitian ini mendukung penelitian Riantoko et al. (2017). Adanya dorongan pada diri seseorang atau motivasi akan meningkatkan persepsi karyawan terhadap dukungan organisasi, kebijakan dan prosedur organisasi, penerimaan sumber daya, interaksi dengan rekan organisasinya (supervisor) dan persepsi mereka mengenai kepedulian organisasi terhadap kesejahteraan mereka (Eisenberger dan Rhoades, 2002:698). Karyawan yang telah mendapat dukungan organisasi dan motivasi pada dirinya maka karyawan tersebut dapat lebih bertanggung jawab untuk berkontribusi dan memberikan kinerja terbaik untuk organisasinya. Pengaruh dukungan organisasi terhadap kinerja karyawan akan semakin kuat jika adanya motivasi dari dalam diri karyawan. Dukungan Organisasi dapat menjadi motivasi seorang karyawan untuk bekerja dan berpengaruh terhadap kinerja karyawan. Dengan adanya motivasi intrinsik terhadap karyawan, maka akan lebih meningkatkan pengaruh dukungan organisasi terhadap kinerja karyawan PT. Bina Artha Ventura.

\section{KESIMPULAN DAN SARAN}

\section{Kesimpulan}

Berdasarkan pembahasan hasil penelitian yang telah dikemukakan di atas maka dapat diambil kesimpulan bahwa terdapat hubungan yang positif dan signifiksn secara sendiri-sendiri maupun secara bersama-sama antara keadilan distributif kompensasi, keadilan prosedural kompensasi, dan dukungan organisasi terhadap kinerja karyawan. Selain itu, penelitian ini juga membuktikan bahwa pengaruh faktor keadilan kompensasi dan dukungan organisasi terhadap kinerja karyawan alkn semakin kuat dengan motivasi intrinsik sebagai variabel moderasi.

Berdasarkan pembahasan, hasil penelitian dan kesimpulan yang telah dilakukan, maka terdapat saran yang dapat diberikan sebagai berikut: 1) Untuk perusahaan, organisasi memberikan kesempatan kepada karyawan untuk dapat memberikan masukan atau koreksi jika merasakan adanya ketidakadilan dalam pemberian kompensasi, 2) Organisasi harus membuat sistem kompensasi yang adil, yaitu berdasarkan tuntutan pekerjaan, ketrampilan individu dan sesuai standar UMR tempat organisasi menjalankan aktivitas kerjanya, 3) Organisasi memberikan reward atau penghargaan jika ada karyawan yang berhasil meningkatkan kontribusi mereka dalam melakukan pekerjaanya.

Untuk Penelitian Selanjutnya, Bagi peneliti selanjutnya yang ingin melakukan penelitian atau melanjutkan penelitian, disarankan untuk meneruskan atau melakukan pengembangan penelitian ini dengan mencari faktor-faktor lain yang memengaruhi kinerja karyawan yang tidak diungkap dalam penelitian ini. Sehingga diharapkan untuk penelitian selanjutnya dapat mengungkap kinerja karyawan berdasarkan faktor-faktor lain.

\section{DAFTAR PUSTAKA}

Abdurrahman, M.S., Purnomo, R., Jati, E.P. (2019). Pengaruh Motivasi Kerja Otonom dan Internal Locus of Control Terhadap Kinerja Karyawan dengan Employee Engagement Sebagai Variabel Mediasi. Jurnal Performance. Vol 26 (2), hal 66-76. 
Afzali A., A.A. Motohari, L. Hatami-Shirkouhi. (2014). Investigating the Influence of Perceived Organizational Support, Psychological Empowerment and Organizational Learning on Job Performance: an Empirical Investigation. ISSN: 1848-6339.

Eisenberger, R., Fasolo, P. and LaMastro, V.D. (1990). "Perceived organizational support and employee diligence, commitment, and innovation", Journal of Applied Psychology, Vol . 75 No. 1 pp. 51-59.

Firmandari, N., (2014). Pengaruh Kompensasi terhadap Kinerja Karyawan dengan Motivasi Kerja sebagai Variabel Moderasi. EKBISI, Volume IX, Nomor 1, ISSN: 1907-9109.

Ghosh, D., T. Sekiguchi, L. Gurunathan. (2017). Organizational Embeddedness as a mediator between Justice and in-role Performance. Journal of Business Research, 75: 130-137.

Ghozali, Imam. (2011). Aplikasi Analisis Multivariate dengan Program IBM Spss 19. Badan Penerbit Universitas Diponegoro: Semarang.

Handoko, T. Hani. (2000). Manajemen Sumber Daya Manusia, Edisi pertama. BPFE: Yogyakarta.

Handoko, T. Hani. (2001). Manajemen Personalia dan Sumber Daya Manusia, Edisi Kedua. BPFE: Yogyakarta.

Hartono, Jogiyanto. (2011). Metodologi Penelitian Bisnis. Edisi Keempat. BPFE: Yogyakarta.

Hasibuan, Malayu, S.P. (2002). Manajemen Sumber Daya Manusia. Penerbit Bumi Aksara: Jakarta.

Hasibuan, Malayu, S.P. (2013). Manajemen Sumber Daya Manusia. Edisi Revisi. Penerbit Bumi Aksara: Jakarta.

Mangkunegara, A. Prabu. (2009). Manajemen Sumber Daya Manusia. Remaja Rosdakarya: Bandung.

Mangkuprawira, S. \& A.V. Hubeis. (2007). Manajemen Mutu Sumber Daya Manusia. Penerbit Ghalia Indonesia: Bogor.

Mathis \& Jackson. (2000). Manajemen Sumber Daya Manusia. Salemba Empat: Jakarta.

Mathis \& Jackson. (2006). Manajemen Sumber Daya Manusia. Salemba Empat: Jakarta.

Muryanto, Eko. (2011). Pengaruh kompensasi terhadap Kinerja dengan Motivasi Kerja sabagai Variabel Moderating pada Kantor Pengawasan dan Pelayanan Bea dan Cukai tipe Madya se-Jawa Tengah dan Daerah Khusus Istimewa Yogyakarta. Universitas Sebelas Maret Surakarta.

Rhoades, L \& R. Eisenberger. (2002). Perceived Organizational Support: A Review of the literature. Journal of Applied Psychology, 87(4): 698-714.

Rivai, Veithzal. (2004). Kepemimpinan dan Perilaku Organisasi. Raja Grafindo Persada: Jakarta.

Rivai, Veithzal. (2005). Manajemen Sumber Daya Manusia untuk Perusahaan. Raja Grafindo Persada: Jakarta.

Sigit, Suhardi. (2003). Esensi Perilaku Organisasi. Penerbit Lukman Offset: Yogyakarta.

Simanjuntak, Payaman. (2005). Manajemen dan Evaluasi Kinerja. Lembaga Penerbit Fakultas Ekonomi UI: Jakarta.

Suhartini. (2005). Keadilan dalam pemberian Kompensasi. Edisi Khusus JSB On Human Resources. Hal. 103-104.

Tjahjono, H.K. (2007). Keadilan Distributif dan Keadilan Prosedural dinilai Adil bagi sebagian Karyawan. Universitas Gajah Mada: Yogyakarta. 